\title{
Expert panel to judge on deep sea disposal
}

London. Tim Eggar, Britain's minister for industry and energy, has set up an international panel of scientists and engineers to evaluate the technical issues raised by the disposal of the Brent Spar oil storage platform, and to appraise new proposals put forward by the oil company Shell.

The panel will be led by the governmentfunded Natural Environment Research Council (NERC), which favours deep-water disposal of Brent Spar, currently moored off the Norwegian coast following a decision by Shell, its owners, to abandon previous plans to dump the platform in the North Atlantic (see Nature 376, 378; 1995).

Both the membership and terms of reference of the committee have yet to be finalized. But Eggar, who opposes the on-shore dismantling of the Brent Spar, said last week that deep-sea disposal would remain the "environmental benchmark" against which other options would be judged.

The announcement was made after an independent audit of the Spar's contents challenged a previous estimate by the environmental group Greenpeace - which was primarily responsible for Shell's earlier decision to abandon deep-sea disposal - of the amount of oil it contained.

The audit, performed by the Norwegian certification agency Det Norske Veritas (DNV), calculated the oil content at between 75 and 100 tonnes, relatively close to Shell's estimate of 53 tonnes. In addition, despite Greenpeace's claims, it found no evidence of toxic materials, and negligible quantities of radioactive waste.

But the impact of the report was immediately undermined by evidence of an internal split within Shell over the company's next step, when two senior officials made apparently contradictory statements about the
Brent Spar's eventual fate.

At a press conference in London following the audit results, John Wybrew, Shell's director of corporate affairs, said twice that deep-sea disposal of the platform had been ruled out. But this was subsequently described as "premature" by Eric Faulds, manager of the Brent Spar audit project.

Wybrew claimed the audit results "put to rest" Greenpeace's "grossly overestimated" calculations of the contents of the platform,

\section{IMAGE \\ UNAVAILABLE FOR COPYRIGHT REASONS}

Where next? Shell has promised to listen to public opinion over the ultimate fate of the Brent Spar

and stressed the company would now concentrate on "finding a new solution", which "manifestly rules out deep-water disposal". The company has so far received 250 proposals after inviting suggestions for how disposal should be achieved.

But Wybrew also acknowledged that Shell had made a mistake in ignoring public concern about deep-water disposal, saying that any future decision to dispose of a disused offshore oil installation should not be based solely on scientific, economic and environmental considerations. "Political and public considerations will take greater

\section{Astronomers seek a 'defence' agency}

Boston. An international meeting of astronomers has agreed to promote the setting up of a network of telescopes to search for and monitor 'near-Earth objects' (NEOs) - asteroids or comets that may pose a threat to life on this planet - in line with a proposal made in 1992 by a panel set up by the US National Aeronautics and Space Administration (NASA).

The meeting, which was sponsored by the International Astronomical Union and held on the Italian island of Vulcano last month, proposed that this should be done through an international agency, to be known as the 'Spaceguard Foundation'.

"No existing agency currently supports this effort," says Eugene Shoemaker of the Lowell Observatory. Even the International Astronomical Union's NEO working group, headed by the Italian astronomer Andrea
Carusi, who also chaired the Vulcano proceedings, has only "a finite lifetime and essentially no budget". The foundation hopes to secure financial backing from govuals, and then distribute funds to researchers. But Carusi says that raising money is not the main goal. "We want worldwide recognition that this is important work that needs to be done. With that recognition, the money should come."

"The key thing is to broaden the effort and make sure it's not just a US operation," adds David Morrison, the astronomer from the NASA's Ames Laboratory who led the original Spaceguard panel. "The foundation will focus on countries other than the United States, which already has an observation programme - albeit one that some people consider inadequate." Steve Nadis ernment agencies, corporations and individ- priority [than at present]," he said.

Nevertheless, Shell continues to insist that deep-water disposal remains a viable option. A spokeswoman for the Department of Trade and Industry said later that Chris Fay, the chief executive of Shell UK, has confirmed to Eggar that "deep-water disposal remains an option for Brent Spar", particularly in the light of the audit results.

A campaign by Greenpeace - including coordinating a Europe-wide boycott of Shell petrol-filling stations -

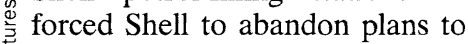
\& $\underset{\propto}{\times}$ peace claimed the sinking would amount to an environmental catastrophe.

Wybrew's proposal - confirmed by a Shell spokesman - to allow the public to influence a decision on Brent Spar, is likely to be controversial, and may not be supported by the government.

A spokeswoman for the DTI says the department would not speculate on the relative importance given to public acceptability until a proposal from Shell is on the table. But Greenpeace welcomed the development. Any decision to dispose of Brent Spar must take account of public opinion, says its spokesman, Adam Woolf. "Science plays a vital role," says Woolf. "But it cannot be the sole arbiter of truth and wisdom, because it is often value-driven, too."

The argument about the fate of the Spar, has overshadowed what is arguably an equally important issue: Greenpeace's ability to influence public opinion using information that, according to Ole-Andreas Hafnor, senior vice-president of DNV, "contained major errors of misinterpretation".

Although the DNV report points out inaccuracies in both Shell and Greenpeace data, Greenpeace's errors are more substantial. For example, the auditors found no evidence to support a sworn affidavit from a former Shell employee who claimed three barrels of toxic waste had been hidden on Brent Spar. The amount of "naturally occurring" radioactivity was too small to be classified as radioactive waste, Hafnor added.

But Woolf says that while Greenpeace acknowledged errors in estimates for oil on the Spar, the campaign was never about it's contents. It was about setting "acceptable standards of behaviour" and "not treating the sea as a global dustbin".

Meanwhile, Robert May, the government's chief scientific adviser, said at a conference in Oxford last Friday that the matter underlined the need for a better early warning system within government to identify in advance issues such as those raised by the public controversy over the Brent Spar disposal. 